\title{
Academic Detailing
}

National Cancer Institute

\section{Source}

National Cancer Institute. Academic Detailing. NCI Thesaurus. Code C20054.

An approach to educating physicians in their offices. It uses relatively inexpensive,

focused educational mechanisms that can be used during short one-on-one conversations with physicians. 